\title{
O SONHO DE FREUd: SEMIÓTICA DO DISCURSO ONÍRICO
}

\author{
Waldir Beividas ${ }^{1}$ \\ Universidade Federal do Rio de Janeiro
}

\begin{abstract}
$O$ autor toma o texto da Interpretação dos Sonhos de Freud, mais precisamente, o próprio sonho maior aí analisado, da injeção em Irma, para defender a idéia de que o criador da psicanálise inaugurou com isso uma reflexão "semiótica" avant la lettre, sobre a espinhosa questão do sentido. Sustenta que, frente ao modo como Freud dispôs seu método de interpretação onírica, as análises lacanianas desse sonho merecem reparos, justamente porque careceram de uma discussão maior sobre a questão freudiana do acúmulo de significações do sonho, ressentiram-se de um diálogo, não havido no tempo, entre a psicanálise e as teorias que têm o sentido como objeto precípuo de investigação (teorias do discurso e semióticas). Entende que as razões desse déficit devam ser debitadas ao modo como a psicanálise lacaniana e pós-lacaniana conduziram o conceito de sentido, paulatinamente desdenhado e abandonado, senão mesmo abertamente excluído de suas cogitações atuais.
\end{abstract}

Descritores: Psicanálise. Semiótica. Sonho.

Tu quoque, Brute, fili mi !

o singular tabuleiro do xadrez psicanalítico costuma-se iniciar o jogo
pelo modo já tornado clássico: a abertura Freud. E um dos peões que sai à frente, quase mesmo a marcar o estilo das jogadas futuras, o próprio enxadrista, criador do jogo, o estimou como a via real de acesso ao xequemate, por assim dizer, do indomável inconsciente: o sonho. Mas esse peão

1 Professor Adjunto do Programa de Pós-Graduação em Teoria Psicanalítica da UFRJ; Doutor em Semiótica e Lingüística pela USP; pós-doutoramento pela EHESS - Paris . Endereço eletrônico: waldirbeividas@yahoo.com.br 
não foi apenas um simples objeto, conquanto privilegiado, para o interesse freudiano. O sonho contém em si não só o cenário (a "outra cena") onde o inconsciente se legitima mais patente. Melhor que isso, apresenta um conjunto enorme de estratégias de composição do próprio cenário, das personagens e suas falas, estratégias que exibem uma movimentação ou expressão truncada pela qual o inconsciente se exibe, talvez mesmo se construa, latente e latejante, como pulsação escondida, insistente. E, uma vez entendidas as estratégias, como trabalho próprio do sonho, elas revelaram a Freud os segredos do sonho - tal como escrito na lápide de seu imaginário entusiástico, confidenciado ao amigo Fliess - ou então, menos ambiciosamente, indicaram o sentido do sonho, na dupla acepção: sua semântica e sua direção, qual seja, uma expressão, atualização ou realização furtiva de desejos. E isto foi certamente sua conquista real: a psicanálise ficou assim disposta no tabuleiro.

Isso significa que a jogada de maior fôlego da vida inteira do enxadrista do sonho encerra não uma, mas três teses maiores, duas delas, de resto, já indicadas no título de sua obra-prima, Traumdeutung: a) há sentido, o sonho é algo dignus intrare (no âmbito da pesquisa científica), não é um absurdo non sense, e sim pleno de sentidos, a indicar o dinamismo ímpar do inconsciente; b) há interpretação - explicação, investigação, ciência, saber (deutung é sempre difícil de traduzir) - efetiva e necessária para acompanhar os itinerários do sentido; e c) há desejos que aí se expressam, uma vez levada a cabo a interpretação do seu sentido. Desejo, interpretação e sentido, essa tríade freudiana catalisa o acesso ao mundo do sonho (e do inconsciente). Não importa muito de onde se parte: para captá-lo como realização de desejos, é preciso interpretá-lo nos seus sentidos, nas camadas disfarçadas que os ocultam; para que seja interpretável é preciso que o sonho apresente uma camada (espessa) de sentidos a ser atravessada, após o que - habemus desidera - o sonho se revele como desejos; por fim, haver sentido(s) é tese necessária para que, afinal, algum deles seja interpretável como o desejo mobilizador do sonho, algum outro como desejo inconsciente (sexual, infantil...), pré-consciente etc. Noutros termos, esse tripé monta uma disposição de tal forma coesa do tabuleiro, que a falta ou desleixo na movimentação de uma das peças derruba em cascata as outras, e o jogo fica perdido. 
Interpretação, desejo, sentido, a tríade está longe de ter tido desenvolvimentos satisfatórios, a despeito mesmo de todo o avanço da psicanálise freudiana, bem como da intervenção lacaniana e pós-lacaniana. A interpretação, porque, ao invés de assumir por inteiro o estatuto semiótico (o registro do sentido) de suas teses - para enfrentar no seu próprio nível epistemológico as fortes críticas, como por exemplo, as que um Grünbaum (1984) desfere contra as posições semiótico-hermenêuticas de Habermas ou de Ricoeur -, a psicanálise pós-lacaniana prefere enfatizar uma espécie de abandono da "arte interpretativa" do primeiro Freud, em prol da tarefa de "construção" do último, como se com a pretensa troca a coisa pudesse ser contornada ou ultrapassada; o desejo também ficou deficitário, porque, questão igualmente incômoda, ele parece deslocar-se continuamente em toda análise, sendo, pois, difícil estabelecer uma esfoliação fina das suas camadas para assegurar quando adentra pra valer a região de estatuto inconsciente. Declará-lo sexual, aplicar-lhe alguma maiúscula ou adjetivo reforçativo não parece suficiente para ver resolvida a dificuldade. Por fim, o sentido, a questão teórica mais séria, foi, de início, peça inteiramente posta no tabuleiro por Freud, em seguida, engenhosamente "movimentada" por lances estruturalistas de Lacan, nos anos 50 do século passado para, logo depois, ser mal conduzida, justamente ao expor-se como álibi para, finalmente, ser abandonada na prática investigativa, ser mesmo banida para fora dos conceitos mais pregnantes da teoria, nos dias de hoje, enfim, cair fora do tabuleiro ( $c f$. a tese milleriana «fora-do-sentido» como veremos adiante).

Não sendo, entretanto, o tema central deste artigo examinar em detalhe essa carência tríplice, a questão do sentido é a que ocupará o espaço aqui disponível, maneira de ilustrar localmente tal déficit. Assim, vejamos, por primeiro, como o criador do jogo começou a dispô-la no seu tabuleiro; em seguida, como Lacan se serviu dela em alguns de seus lances; e, por fim, que balanço tirar do modo como ela está disposta na psicanálise pós-lacaniana, na sua vertente milleriana, a mais difundida. 


\section{Freud à letra}

Não pareço trair o consenso em psicanálise ao entender que os anos da investigação freudiana da Traumdeutung foram a sua travessia do Rubicão. O alea jacta est freudiano foi o passo de adscrever o sonho - e de resto, toda a psicanálise do inconsciente, uma vez riscada por aquele a estrada real de acesso a este - no registro da cifragem e decifragem do sentido (psicológico). Foi assim que, na letra dos seus textos posteriores - cito logo abaixo uma passagem sobre os atos falhos - testemunha que pedira licença, por assim dizer, para retirar sua psicanálise do registro fisiológico ou biológico, em prol do registro do sentido ${ }^{2}$ :

Si conseguimos demostrar que las equivocaciones orales que presentan un sentido, lejos de constituir una excepción, son, por el contrario, muy frecuentes, este sentido (...) vendrá a constituir el punto más importante de la misma [investigação] y acapará todo nuestro interés, retrayéndolo de otros extremos. Podremos, pues, dar de lado todos los factores fisiológicos y psicofisiológicos y consagrarnos a investigaciontes puramente psicológicas sobre el sentido de los actos fallidos; esto es, sobre su significación y sus intenciones (1915-17/1973, p. 2138).

Assim como para o caso dos atos falhos, se quisermos pegar o sonho freudiano pelo chifre, pela cifra da sua letra, a coisa toma a mesma direção clara «interpretar un sueño» quiere decir indicar su «sentido» (Freud, 1900/1973, p. 406 - as aspas francesas, no original, não me parecem simples ênfase, mas argumento definitório). É desse modo que Freud abre o segundo capítulo do seu xadrez onírico, justo aquele em que propõe um método para isso: El método de la interpretación onírica. É também, na verdade, como tivera já aberto a própria partida global com estes auspícios: a técnica que descobrira revela que cada sonho é "un producto psíquico pleno de sentido" (p. 349, itálicos nossos). São inúmeras as vezes que o entusiasmado descobridor do enigma dos sonhos repete o lance:

2 Para evitar os embaraços de uma tradução de tradução, preferi utilizar em todo o artigo a de Luis Lopes-Ballesteros y de Torres, feita do original alemão (1973, em 3 Tomos). 
El sueño posee con frecuencia varios sentidos. No sólo pueden yuxtaponerse en él - como hemos visto en algunos ejemplos - varias realizaciones de deseos, sino que un sentido, una realización de deseos puede encubrir a otra (...). (1900/1973, p. 480, itálicos no original)

Não quer isso dizer que, uma vez reconhecido como fato evidente o pleno de sentido do sonho, as coisas fiquem facilitadas. Ao contrário, é a própria disposição das dificuldades, justamente porque resulta um acúmulo por demais emaranhado de significações, a pedir paciência de artesão ao intérprete para deslindar a fiação sutil do desejo:

La acumulación de significaciones del sueño es uno de los problemas más arduos y al mismo tiempo más ricos en contenido de la interpretación onírica. Aquellos que olviden esta posibilidad incurrirán fácilmente en graves errores y sentarán afirmaciones insostenibles sobre la esencia del sueño. Pero sobre esta cuestion no se han realizado aún sino muy escasas investigaciones (...) (1900/1973, p. 480, em nota de rodapé, itálicos meus).

De que modo, então, Freud dispõe a busca e interpretação do sentido na sua teoria e técnica analítica?

\section{Via di porre vs. via di levare}

Ao longo da obra freudiana, uma metáfora se repete na composição da técnica analítica de interpretação do sentido dos sonhos, do sintoma, dos atos falhos. Desde seus primeiros Estudios Sobre la Histeria (Freud, 1895/1973, pp. 39-168) - em que justificava, quase mesmo se desculpava com o leitor pela excessiva importância que concedia aos detalhes minúsculos dos sintomas, "sus más sutiles matices", no seu trabalho interpretativo, alertava justamente que "nunca se peca por exceso atribuyendo a los mismos un sentido" (p. 83, em nota de rodapé). Freud compara a sua técnica à escavação de uma antiga cidade. A esperança é, após penetrar os estratos psíquicos mais profundos, conseguir aí descobrir "una determinación completamente suficiente" (p. 110). A metáfora vai se repetir, quase intacta, no apagar de sua obra. O trabalho analítico de "construção" - ou se se prefere de reconstrução, acrescenta Freud em texto tardio, destinado a ficar famoso - se parece muito a uma "excavación arqueológica” (1937/1973, p. 3366). 
Mas é no entretempo desses textos que encontramos a reflexão mais instigante. Freud defende agora sua técnica contra a técnica da sugestão (hipnótica), para dissipar qualquer confusão entre elas. Assim, em sua pequena conferência pronunciada no Colégio de Médicos de Viena, Sobre Psicoterapia (1904), acentua a máxima oposición entre as duas técnicas, e evoca para isso a distinção que Leonardo da Vinci estipulara para as artes: per via di porre é a operação pela qual a pintura parte de uma tela vazia e branca e lhe põe cores onde nada havia; per via di levare é a operação da escultura que extrai da pedra bruta a "masa que encubre la superficie de la estatua en ella contida". Nessa oposição maximizada, o psicanalista define a sua técnica, a segunda:

\footnotetext{
En cambio, la terapia analítica no quiere agregar nada, no quiere introducir nada nuevo, sino, por el contrario, quitar y extraer algo, y con este fin se preocupa de la génesis de los síntomas patológicos y de las conexiones de la idea patógena que se propone hacer desaparecer. (1904/1937, p. 1009, itálicos meus, que serão encarecidos na sequiência da argumentação)
}

O recurso emprestado por Freud às definições de Leonardo, a metáfora da escultura para a sua técnica analítica não pode ser declarada perfeita. A ênfase do psicanalista, por certo, está voltada à prudência de interferir o menos possível nos dados que o paciente traz à escuta; está voltada à habilidade em evitar a fúria interpretante ou a hiperinterpretação que agregue ou colore excessivamente os dados, sem o devido lastro. A metáfora da escultura não é perfeita porque, de uma mesma pedra bruta, as imagens saem diferentes se das mãos do próprio Leonardo, de um Rodin ou do nosso Aleijadinho. Nenhuma técnica extrativa, mesmo per via di levare, poderia ser conduzida em psicanálise com uma escuta/análise de neutralidade absoluta, ainda que apostada como um horizonte desejado. Não há um grau zero da análise ou escuta clínica, sempre haverá a mão de um artista. Mas é a nosso ver a melhor metáfora possível, porque metodologicamente realista. Se não forte método, há salutar disciplina interpretativa na opção adotada.

Para meus propósitos aqui, convém traduzir que, assim escolhendo, Freud circunscreve o dispositivo ou técnica analítica na imanência do discurso (do paciente): nada agregar de fora, nenhuma cor nova a ser-lhe pinta- 
da, a não ser extrair das suas minúcias, dos seus detalhes, dos seus matizes sutis, das remissões ao contexto geral da clínica, ou de qualquer outro texto em exame, extrair dele e somente dele as suas determinações suficientes. Ora, não me parece que todos os psicanalistas levaram em devida conta essa tese imanentista de Freud. E para exemplificá-lo, escolho o maior deles, Lacan (1954-5/1992, pp. 187-217), na interpretação que colhe do sonho da injeção em Irma, de Freud, e acrescento, no andamento do jogo, alguns lances da interpretação recente de Zizek (2001).

\section{O sonho da injeção em Irma (de Freud) ${ }^{3}$}

Um grande salão - muitos convidados que nós recebemos - dentre eles, Irma, de quem logo me aproximo, para responder sua carta e fazer-lhe recriminações, visto que ainda não aceita a «solução». Digo-lhe: "Se ainda tem dores, a culpa é realmente sua". Ela respondeu: "se soubesses as dores que tenho na garganta, no estômago e no ventre. Tudo me confrange". Espanto-me e olho para ela. Parece pálida e inchada. Penso: no final dou-me conta aí de algo orgânico. Levo-a à janela e olho sua garganta. Ela apresenta alguma resistência, como as mulheres com dentaduras postiças. Penso comigo que aquilo não é necessário para ela. A boca abre-se bem, e eu encontro uma grande mancha, e noutra parte vejo notáveis produtos enrugados, extensas crostas cinza-esbranquiçadas, que evidentemente copiava a concha nasal. Chamo rapidamente o Dr. M., que repetiu o exame e o confirmou... Dr. M. parece mais diferente que nunca, está pálido, claudica e está sem barba no queixo... meu amigo Otto está também de pé agora perto dela, e

3 Por economia de espaço, reproduzo aqui apenas o sonho relatado, sem os comentários que Freud, em seguida, faz para cada segmento, os quais, por sua vez, serão retomados à medida do exame. Também preferi apresentar uma tradução direta do alemão, feita por Lina Carvalho Schlachter, pelo que sou grato, com vistas a pelo menos, contornar os embaraços das traduções -de-traduções, disponíveis em português. De toda forma, as diferenças são mínimas nesse episódio, e não comprometem a essência do que quero ilustrar. 
meu amigo Leopold a ausculta sobre o ventre e diz: "ela tem um abafamento abaixo à esquerda", indica também uma parte da pele infiltrada no ombro esquerdo (o que noto como ele, apesar da roupa)... M. fala: "sem dúvida é uma infecção, mas não tem importância, sobrevirá uma disenteria e o veneno será eliminado"... nós também sabemos de imediato de onde vem a infecção. Quando ela não se sentia bem, o amigo Otto, recentemente, deu a ela uma injeção com preparado de prolil, propileno, ácido propiônico... trimetilamina (vejo sua fórmula, diante de mim, em negrito)... não se faz injeções tão levianas... provavelmente a seringa também não estava limpa.

A cada segmento do sonho acima anotado, o sonhador Freud oferece um sem-número de associações, lembranças, circunstâncias, permeadas de suspensões, sentimentos avaliativos, comentários à margem, em nota de rodapé, marcas de exclamações em lugares especialmente delicados. Há truncamentos de passagens e de "muchas indiscreciones", omissões e evitações, até mesmo falsificações ("suplantando algunas cosas") que Freud reconhece, já de antemão, como inevitáveis, admitindo, por isso, "perjudicar sensiblemente" o valor dos exemplos com que quer ilustrar (1900/1973, p. 344 - Prefácio à $1^{a}$ edição). Ora, nada disso depõe contra o sonhador. Seu texto, ou sua fala, é soberano, seu contexto imediato ou distante, as lembranças de sua memória, a modulação de seu discurso, seus temores, ênfases, suspensões, falsificações e mesmo a escolha dos momentos em que faz cortes, notas de rodapé, comentários marginais, tudo constitui a imanência do texto e contexto a servir de material à interpretação. De modo que, se algo não puder ser inferido das marcas, linhas e entrelinhas do texto e conteto, se algo não puder ser extraído da argamassa de pedra que esconde a estátua do(s) desejo(s) do sonhador, per via di levare, não poderá ser declarado como pertinente à técnica da análise. Lacan e Zizek não parecem ter, no episódio, cumprido os quesitos. 


\section{O sonho de Freud (por Lacan e Zizek) ${ }^{4}$}

Convém apresentar, primeiramente, duas precauções de método pelas quais Lacan mantém seu público em alerta. A primeira é de não querermos fazer o primeiro Freud ter dito o que terá dito o último Freud, acordar as etapas de seu pensamento numa sincronicidade ilegítima. Na segunda boa precaução, o comentador freudiano mais notável adverte, sobretudo, sobre o manejo respeitoso que se tem de ter para com o texto:

(...) vocês constatarão de sobra que só o manejamos com o maior respeito (...). Deve-se partir do texto e partir dele, como Freud o faz e aconselha, como de um texto sagrado. $\mathrm{O}$ autor, o escriba, é apenas um escrevinhador, e vem em segundo lugar. Os comentários das Escrituras ficaram irremediavelmente perdidos no dia em que se quis fazer a psicologia de Jeremias, de Isaías, inclusive, a de Jesus Cristo. Da mesma maneira, quando se trata de nossos pacientes, peço-lhes que prestem mais atenção ao texto do que à psicologia do autor - é a orientação toda do meu ensino (Lacan, 1954-5/1992, pp. 195, itálicos meus).

É certo que esses alertas salutares se põem num estilo um tanto apimentado de ironias e desdém ao modo interpretativo de um outro psicanalista. É o caso da crítica que dirige contra Erikson e a escola culturalista de que este se utiliza, que concede toda ênfase da análise para o contexto cultural em que o sujeito está mergulhado, o que, ao ver de Lacan, vai de mãos dadas ao psicologismo de querer entender todo o texto psicanalítico como função das diferentes etapas do ego (p. 189). A pimenta, o psicanalista francês a salpica aqui e ali: grand bien lui fasse (que faça bom proveito) diz o psicanalista (p. 189), sobre o culturalismo da leitura de Erikson, claro com a conotação de sua língua materna que implicita aí um «duvido fortemente que algo de bom saia disso». Em outro episódio, o comentário do culturalis-

4 Os limites do artigo impõem severos cortes. Os dois capítulos que Lacan dedica ao sonho de Freud, em seu seminário (1954-5/1992, pp. 187-204), são deveras ricos. Valeria a pena serem investigados minuciosamente, dadas as questões que suscitam e que, pelas escolhas temáticas das duas sessões do seminário, não foram muito desenvolvidas pelo próprio Lacan. O texto de Zizek (2001), baseado claramente no de Lacan, acrescenta alguns dados interpretativos, que parecem exigir os comentários a que me proponho. 
ta "...é bastante divertido. Conseqüência do culturalismo que não serve aqui para abrir os olhos do Sr. Erikson" (p. 196), que move uma série de "brinquedinhos psicológicos, certamente muito instrutivos, mas que me parecem, na verdade, ir contra o próprio espírito da teoria freudiana" (p. 198). Justiça se faça, no entanto, ao irônico freudiano: por vezes, elogia e, até mesmo, utiliza partes da interpretação do outro. Infelizmente não leva adiante uma difícil discussão: "deixemos, por ora, de lado a discussão teórica que isso pode levantar" interrompe-se Lacan (p. 189). A discussão que não retoma na seqüência, discussão tão difícil quanto necessária - sempre à vista do tabuleiro freudiano, do "acúmulo de significações" que nos interessa de perto aqui - é aquela de como estabelecer até onde o texto em exame pode ser ampliado ao contexto (da análise, da cultura, da vida, das etapas do ego) como pertinente à extração ou escultura per via di levare de alguma estátua do sujeito em exame ${ }^{5}$.

Ocorre, porém, que, no episódio do sonho de Freud, não me parece terem sido cumpridas inteiramente as precauções sobre as quais Lacan adverte. De fato, uma série de reparos pode ser feita no modo como conduz a interpretação ${ }^{6}$ :

1. Frau Doktor. Para criticar a importância que Erikson atribui ao plural "recebemos" (os convidados da família Freud para a festa de aniversário da mulher), Lacan interpreta que, apesar do plural, isso não implica a duplicidade da função social de Freud e completa: "pois não se vê absolutamente

5 É de fato enorme a questão que, nas diversas teorias do discurso e críticas literárias, demarca-as calorosamente em métodos de descrição imanentes ao texto, frente a direções transcendentes ao texto, ao intertexto, ao contexto. Es se foi, por certo, um capítulo em branco de diálogo não havido entre psicanálise e teorias do discurso, pela interrupção lacaniana do diálogo com a lingüístic a de sua época. A esse respeito, confira-se Beividas (2002, pp. 179-190; Parte III) e Beividas e Lopes (2004).

6 Os limites do presente artigo impedem examinar as ocorrências em detalhes. Levanto aqui apenas o que me pareceu mais problemático e sobressalente. Por sua vez, o próprio material de análise oferece um potencial de acúmulo de significações tão rico e extenso que se roga ao leitor resignar-se ao pouco aqui apresentado, para, em seguida, poder conferi-lo, sendo, pois, vivamente convidado, ele mesmo, a ir ao texto da interpretação do próprio Freud, como ao do seu discípulo mais carismático. 
aparecer a prezada Frau Doktor sequer um minuto" (1954-5/1992, p. 196). Não dá para concordar com Lacan. Freud contextua o sonho às vésperas do aniversário dela, traz resíduos da conversa sobre isso no dia anterior, insere várias vezes sua mulher no sonho (bem entendido: sonho, relato e associações do sonhador). Mesmo porque, o próprio Lacan, logo em seguida, reconhece a presença "problemática" no primeiro trio condensatório de Irma, junto à amiga desta, da mulher de Freud. Mas o problemático mesmo é quando acrescenta: "que, naquele momento, como se sabe por outros meios, está grávida..." (p. 196, itálicos meus). Ora, não se pode agregar à interpretação algo obtido por outros meios que não o texto-contexto sob exame. Como se vê, Lacan incorreu aqui em dois procedimentos via di porre que Freud opunha "maximamente" ao seu método via di levare : apagou uma tinta da tela (a presença da Frau Doktor ) e pintou uma nova cor (a sua gravidez).

\section{Não se trata de exegetar:}

Quando Freud interrompe suas associações, tem lá suas razões. Ele nos diz - Aqui, não posso dizer-lhes mais do que isto, não quero contar-lhes as histórias de cama e penico - ou bem - Aqui não tenho mais vontade de continuar associando. Não se trata de exegetar ali onde o próprio Freud se interrompe... (Lacan, 1954-5/1992, p. 194).

Somado esse comentário ao que vem em seguida, para o mesmo episódio (da entrada em cena condensada da amiga de Irma), Lacan atesta que se trata de um "leque, que vai desde o interesse profissional, o mais puramente orientado até todas as formas de miragem imaginária..." (p. 197), de algo em que, "por fim, as coisas se amarram e chega-se a sabe-se lá que mistério" (p. 200). Ora, é completamente paradoxal ver aqui o psicanalista renunciar ante à "resistência" ou mesmo "recalcamento" de seu paciente em análise, ante à questão da sexualidade.

O sonhador dá todas as dicas disso: a) confessa, primeiramente, ter falseado algumas passagens (cf. acima); b) insere, no exato momento do segmento em que comenta a amiga ("a boca abre-se bem"), um corte alta- 
mente significativo no texto: uma nota de rodapé, na qual admite que a coisa iria bem longe - o famoso "cordão umbilical" - quase como uma baliza fincada no terreno a indicar: eis aqui a coisa ; c) lembra as simpatias que tem pela inteligência da amiga, que Lacan acertadamente anota, e passa por cima, como "jovem mulher sedutora" (p. 197); d) evoca as lembranças de exames médicos e de "pequeños secretos, descubiertos durante ellos para confusion de médico y enfermo" (Freud, 1900/1973, p. 414); e) a dentadura postiça o remete a um elogio à Irma, "pero sospecho que encierra aún otro significado distinto. En un análisis nos damos siempre cuenta de si hemos agotado o no los pensamientos ocultos buscados" (Freud, 1900/1973, p. 414); f) o comentário curioso de Freud sobre os diagnósticos apesar da roupa o remete ao costume de desnudar as crianças, em contraposição ao modo como examina pessoas adultas, associações que assim arremata: "a partir de aquí se oscurecen mis ideas, o dicho francamente, no me siento inclinado a profundizar más en esta cuestión" (Freud, 1900/1973, p. 416); f) igualmente, o comentário, desta vez curiosíssimo, no tocante a trimetilamina - o fator sexual ao qual "adscribo la máxima importancia en la génesis de las afecciones nerviosas", a partir da substância descoberta por seu amigo Fliess: relata que sua paciente Irma é uma jovem viúva, situação para a qual, segundo Freud, seus amigos "pondrían gustosos el remedio" e, atente-se para o mais importante, associação em que se anuncia (ou se denuncia), com direito a ponto de exclamação: "Pero ; observemos cuán singularmente construido puede hallarse un sueño ! La otra señora, a la que yo quisiera tener como paciente en lugar de Irma, es también una joven viuva"(Freud, 1900/1973, p. 418).

Todas essas marcas do texto e contexto - o lugar singular da nota de rodapé, o teores significativos envolvidos, a posição sintáxica dos comentários e mesmo a pontuação exclamativa - todos esses trechos nos revelam retoricamente o forte odor de sexualidade exalando pelos poros do discurso do sonhador. ${ }^{7}$ Fica pois difícil de concordar, e até mesmo surpreendente de

7 Note-se que nem foi preciso incluir aqui as conotações da expressão "o abrir-se" da boca de Irma. Isso porque, do termo alemão - aufgehen - verbo reflexivo emprega- 
constatar, a dessexualização ou, no mínimo, a sublimação desmedida que Lacan promoveu na sua interpretação. Para dizê-lo numa palavra, Lacan tomou a tela fortemente colorida de sexualidade do sonho freudiano e a acinzentou, via di porre, mais uma vez.

3. A garganta de Irma. Um "espetáculo medonho", é o que Lacan faz Freud ter visto:

Eis aí uma descoberta horrível, a carne que jamais se vê, o fundo das coisas, o avesso da face, do rosto, os secretados por excelência, a carne da qual tudo sai, até mesmo o íntimo do mistério, a carne, dado que é sofredora, informe, que [sic] sua forma própria é algo que provoca angústia. Visão de angústia, indetificação de angústia, última revelação do és isto - és isto, que é o mais longínquo de ti, isto que é o mais informe. É diante dessa revelação do tipo Mené, Thequel, Pharsin, que Freud chega ao auge de sua precisão de ver, de saber, até então expressa no diálogo do ego com o objeto (Lacan, 1954-5/1992, pp. 197-198, itálicos no original).

Desta feita, novas fortes tintas acima continuam a colorir a interpretação: imagem horrífica (p. 201), aterradora, imagem da morte (p. 208), revelação do real, do real derradeiro, objeto de angústia por excelência (p. 209). Ora, o texto do sonhador não dá indicações seguras desse dramatismo inflado, hiperbólico e densamente colorido. As únicas expressões de susto, medo, aflição ou temor de Freud são voltadas ao volume dos sintomas que Irma apresenta no sonho, às infiltrações (infecções), discussões sobre difterites e difterias, lembranças da doença da filha, Matilde, da outra Matilde, sua paciente, da sua mulher e de sua própria saúde, à prescrição recriminada da cocaína, enfim, às questões de conscienciosidade profissional, hesitações no seu saber; a morte, sem dúvida se apresenta aqui como tema etc. ${ }^{8}$. Ao con-

do em expressões como «o guarda-chuva abriu-se, a porta se abre, o sol se abre no horizonte, uma semente se abre (germina), etc.» - não estou seguro de que seja passível de ser usado como o português na conotação sexista. Pode-se prescindir comodamente de tal conotação, sem prejuízo do acúmulo de significações bastante sexualizadas do episódio.

8 Noto ao leitor que as contraposições não têm valor de análise exaustiva ou contrastiva do texto, o que não me proponho aqui, apenas procuram conferir se algum traço seu permitiria as numerosas ilações de Lacan. 
trário do elenco dramático e hiperbólico de visões aterrorizantes imputadas por Lacan, o exame da garganta enfatiza uma única modulação da apreensão de Freud no episódio, que exigia alguma explicação: chamar rapidamente o Dr. M. O próprio sonhador se encarrega de explicá-lo: em geral, era corriqueiro, vista a posição que esse D. tinha no grupo; em seguida, no caso específico da pressa, a coisa se devia por estar mesclada à lembrança de um insucesso anterior, no tratamento com um produto perigoso (sulfonal), que havia provocado uma grave intoxicação num doente.

Há outros índices, no texto, a indicar que o sonhador não considerou a cena da garganta de Irma como o dramático espetáculo terrificante da hipérbole lacaniana. Quando Freud se vê ladeado por Otto e Leopold e comenta a cena, diz, textualmente, que eles trabalharam juntos "durante varios años, mientras fui director de un consultório público para niños neuróticos, y con gran frecuencia se desarrollan durante esta época escenas como la que mi sueño reproduce" (Freud, 1900/1973, p. 416, itálicos meus). A cena do sonho reproduzia cenas frequientes de sua atividade médica. Ou seja, parece bem mais razoável deduzir que, tal como um cirurgião de órgãos internos, que, rotineiramente, está às voltas com "a carne que jamais se vê" - para usar apenas uma das abundantes cores da paleta lacaniana -, quando esse tipo de procedimento se torna corriqueiro, adquire uma «frieza semântica», por assim dizer, torna-se, por isso, uma rotina de baixo semantismo, como toda rotina que se vai automatizando pela repetição contínua. Nenhum médico tem uma visão tão assombrosa, na rotina de seus exames, quanto a que Lacan quer desenhar na tela freudiana.

Finalmente, se Lacan acinzentou a tela colorida da sexualidade do sonhador, no episódio anterior, aqui procedeu ao contrário: tomou o cinza esbranquiçado que o sonhador viu na garganta de sua paciente e despejou generosamente na tela seu pincel com tintas brilhantes e quentes (aqui endossado por Zizek). Mais um procedimento pictórico em grande estilo, mas não escultural (ou arqueológico). Noutros termos, e em conclusão aos dois últimos trechos aqui comentados, o discípulo freudiano dessemantizou injustificadamente a pesada conotação sexual investida na amiga de Irma, no penúltimo, e hipersemantizou abusivamente - isto é, em direções que care- 
cem de suficiente lastro no texto em exame - a cena da garganta de Irma, no último trecho. Freud tinha mesmo razão em antecipar que a questão do acúmulo de significações do sonho era de fato um árduo problema...

4. Freud é um durão. As seqüelas do hipersemantismo logo vão comprometer a seqüencia do trabalho interpretativo. Lacan, que havia criticado Erikson de psicologismo, vítima de seu método culturalista, acaba concordando e até adjetivando de excelente o reparo do psicologista quando propõe que o sonhador que não acorda ante um espetáculo tão angustiante (a cena da garganta) só pode ser um "durão" (1954-5/1992, p. 198). Ora, no meu entendimento, essa virtude freudiana não encontra respaldo no texto. Se Erikson a sacou sabe-se lá de qual "brinquedinho psicológico", como Lacan ironiza, logo em seguida, ele próprio tiroura da cartola ou pintoura com a paleta acima comentada. $\mathrm{O}$ episódio parece antes uma coisa mais simples: $\mathrm{o}$ sonho de Freud, naquele momento, continuou normalmente como "guardião do sonho" - uma de suas teses - porque não houve a angústia terrificante tal como a pinta Lacan. Caso contrário, a outra das teses freudianas - de que a angústia provoca o despertar - não valeria para sonhadores "durões".

5. Trimetilamina. $\mathrm{O}$ espetáculo angustiante que Lacan pinta na tela do sonho freudiano dá-lhe ensejo a novo colorido, que aí se mescla: a cena da garganta de Irma foi também entendida por ele como uma "revelação" de tipo bíblico "Mené, Thequel, Pharsin" ( $c f$. citação acima), revelação que, a seu ver, vai se repetir no segundo grande ato do sonho: a trimetilamina, substância química inerente à decomposição do esperma, remetida à sexualidade, fator de máxima importância ao sonhador, cuja fórmula química vê em negrito no sonho e a atribui à pesquisa, que lhe é cara, de seu amigo Fliess, que lhe é caro. Lacan reproduz a fórmula em duas versões na sua interpretação (1954-5/1992, pp. 201-202). Como se não bastasse a trimetilamina ser vista como revelação, e bíblica, outras cores se juntam: a fórmula, que o sonhador vê, química e sexual, se reveste de "oráculo", dado seu "caráter enigmático, hermético"; o analista se permite ir adiante: "pode-se calcá-la na fórmula islâmica - Não há outro Deus senão Deus", visto que para ele a fórmula é "constituída por sinais sagrados". De islâmica a fórmula (AZ) passa a se liberar, em seguida, como um brinquedo: "podemos ficar brin- 
cando com o alfa e ômega da coisa". E mesmo que a isso não se prestasse, caso fosse, por exemplo um $\mathrm{N}$ ao invés de AZ, a coisa "daria na mesma piadinha - poderíamos chamar de Nemo [do latim nemo = ninguém](p. 202), tudo enfim para levar ao ponto "em que a hidra perdeu as cabeças, uma voz que não é senão a voz de ninguém faz surgir a fórmula da trimetilamina" (p. 216, itálicos no original).

Há que se pôr muito boa vontade e fidúcia aguerrida no analista para ver no texto do sonhador lastro para tudo isso. $\mathrm{O}$ negrito de uma fórmula química e seu semantismo mais imediatamente trazido como a aposta freudiana - a sexualidade - acabou por ficar apagado e encoberto pelas cores fortes, religiosas, oraculares, islâmicas e míticas pintadas por cima. É de se perguntar, mais uma vez, se toda essa religiosidade está mesmo na estátua do sujeito, que tem de aparecer per via di levare, ou se acabou surgindo da paleta do pintor per via di porre.

6. O sentido do sonho. Pelo passeio que fizemos através da tela de Lacan, vários sentidos são atribuídos ao sonho freudiano. Isto já esteve previsto pelo próprio sonhador quando monta o tabuleiro de sua Traumdeutung. $\mathrm{O}$ leitor verificará, no entanto, que nem todos os sentidos, ou antes, as colorações veementes dadas a eles por Lacan, tiveram suficiente lastro no texto do sonhador. No andamento da sua interpretação, Lacan vai-nos apresentando os seus resultados: (a) primeiramente, a verdadeira significação do sonho ou sua animação secreta é o desejo freudiano de se inocentar de tudo (19545/1992, pp. 199; 214) ${ }^{9}$; (b) em seguida, o ultimo termo, isto é, aquele que

9 Aqui também Zizek exercita o seu pincel: “Alguns documentos recentemente publicados estabelecem claramente que o verdadeiro foco desse sonho era o desejo de salvar Fliess (...) o verdadeiro culpado pelo fracasso da operação nasal de Irma" (2001, p. 9). O exercício põe duas cores novas: primeiro, agrega (termo que Freud excluia de sua técnica) à análise do texto os tais documentos recentes, isto é, algo fora da imanência do discurso do sonhador, do mesmo modo como Lacan incluíra a gravidez de Frau Doktor "por outros meios" (cf. atrás); segundo, mesmo os tais documentos não são garantia de nada. Embora a pungência do fracasso da operação nasal tenha sido objeto de correspondência delicada entre Freud e Fliess de fevereiro de 1895, mês da operação, até maio, portanto, bem passível de ocupar os antecedentes diurnos do sonho (julho), não parece ter sido Irma (Anna Hammerschlag, 
está por detrás do trio místico, das três mulheres condensadas (Irma, sua amiga e a Frau Doktor), é "pura e simplesmente a morte" (p. 200); (c) depois, há que se destacar também a realidade secreta do sonho como "o verdadeiro valor inconsciente" do sonho de Freud, para Lacan, isto é, a busca da palavra, a busca da significação como tal: "não há outra palavra-chave do sonho a não ser a própria natureza do simbólico” (p. 203). A paleta do sentido prossegue: (d) a fórmula da trimetilamina surge para o analista "no ponto em que a hidra perdeu as cabeças, uma voz que não é senão $a$ voz de ninguém ..." (p. 216, itálicos no original). ${ }^{10}$ Por fim, (e) a tela termina em clímax:

Sou aquele, diz Lacan de Freud, que quer ser perdoado por ter ousado começar a sarar estes doentes, que até agora não se queria compreender e que se proibia a si mesmo de sarar. Sou aquele que quer ser perdoado por isto. Sou aquele que quer não ser culpado por isto, pois se é sempre culpado quando se transgride um limite até então imposto à atividade humana. Quero não ser isto. Em lugar de mim há todos os outros. Sou aí apenas o representante deste vasto, vago movimento que é a busca da verdade onde, eu, me apago. Não sou mais nada. Minha ambição foi ma ior do que eu. A seringa estava suja, sem dúvida. E justamente na medida em que a desejei demais, em que participei desta ação, em que quis ser, eu, o criador, não sou o criador. O criador é alguém maior do que eu. É o meu inconsciente, é esta fala que fala em mim, para além de mim. (pp. 216-217, itálicos no original).

"Eis o sentido deste sonho" arremata, em seguida, para finalizar. Como se vê, o analista abre nova paleta de cores para o sentido da tela do sonho. Não é fácil reconhecer, no texto de Freud, suficientes traços para, além

madrinha de Anna Freud) a vítima, e sim Emma Eckstein ( $c f$. a discussão sobre isso em Masson, 1984, p. 191, nota 1). De toda forma, a única fiança da interpretação em psicanálise é o discurso em exame, não documentos exteriores. Imagine-se o que seria de uma clínica a buscar documentos externos ou posteriores, "por outros meios" na análise do paciente.

10 Nesse último aspecto, devo manter em suspenso alguma apreciação mais abalizada sobre o sentido Nemo, ou do sujeito «acéfalo» que Lacan destila no sonho de Freud, sobretudo porque me pareceu ter avançado a interpretação a partir do comentário ao texto sobre o Narcisismo e Psicologia das Massas (cf. p. 210 e 13). Se assim foi, não se manteve alerta sobre a própria precaução que havia pregado no início da interpretação, como vimos atrás: fazer o Freud do início ter dito (ou sonhado?) coisas que só o Freud posterior terá avançado. 
de extrair o desejo "de no ser responsable del estado de Irma" (1900/1973, p. 421), conotá-lo, quase religiosamente, como um pecador penitente que faz sua contrição de humildade, de ambição e de culpa diante do Criador, seja este o próprio inconsciente. A minúscula aplicada ao termo "criador", por sua vez, não apaga a conotação religiosa, nem o sério problema de um inconsciente «transcendentab. Por sua vez, volta o paradoxo: nessa tela final ficou novamente desaparecida a questão da sexualidade.

\section{Balanço}

O leitor dos comentários acima terá visto que considerei criticamente Lacan, em toda a análise do sonho de Freud, como um pintor per via di porre, em contraposição ao desejado método proposto por Freud, o do escultor per via di levare. A bem dizer, temos de admitir-lhe a maestria desenvolta de um grande pintor. O sonho de Freud fica muito mais majestoso, mais solene, até mesmo mais profundo, mais vibrante e dramático sob a paleta de Lacan. O sonho de Freud, visto por Lacan, parece mais cativante do que o sonho de Freud, visto pelo próprio sonhador. O sonho original, e seus comentários freudianos, parecem ficar bem mais "pobres" em pertinência psicanalítica sem as cores vibrantes com que Lacan o refez.

Mesmo sendo difícil a posição de crítico, mormente quando se refere à figura carismática de alguém como Lacan, a pergunta incômoda, que se impõe, é a de ver respondida se a delicada questão, levantada por Freud, do "acúmulo de significações" do sonho, no caso do sonho de Freud, ficou respondida pelo acúmulo de significações aí introduzidas pela análise lacaniana. Elas se equivalem? As segundas explicam as primeiras? No meu entendimento, salvo engano, não: elas se sobrepõem, tornando duplamente delicada a própria questão. É como querer que o estilo de um autor queira ser explicado pelo estilo de outro. Duplicam-se os estilos e o problema fica, duplicado. A questão do acúmulo de significações do sonho permanece, pois, intacta, desde Freud, como vimos em citação acima: "Pero sobre esta 
cuestion no se han realizado aún sino muy escasas investigaciones." (1900/1973, p. 418)

Lamentavelmente, após mais de cem anos de distância, ainda não podemos dar por cumprida, nem mesmo avançada, na verdade, até mesmo abandonada no tabuleiro, a tarefa de mover as peças com maior cuidado na região do acúmulo de significações do sonho. Muitas e muitas são as razões desse abandono. Para dizê-lo breve e cruamente, o abandono foi sendo acentuado, no andamento da partida, desde Lacan e após Lacan, porque os lances foram jogados cada vez mais para fora da região das questões lingüísticas e da região que lhe completaria posteriormente, isto é, das teorias da significação e dos discursos em geral, fora da região semiótica, fora do registro do sentido. Um plano do significado, paritário ao do significante, de Saussure, plano encarregado pelo lingüista a responder por todo o fenômeno intrincado da significação, do sentido, dos efeitos de sentido, ficou barrado no algoritmo de Lacan. $\mathrm{O}$ significante inchou com a nobreza de uma letra maiúscula e comprimiu com uma barra espessa o significado, condenado a permanecer mal conhecido na sua forma e estrutura, acanhado, minúsculo, insignificante, lançado quando muito ao registro (desprestigiado) do Imaginário. Propagou-se a tese do significante puro, "vazio de sentido", ou antes "sem sentido", como a realização mais perfeita e mais pura do puro significante lacaniano. E hoje, como radicalização decorrente e conclusiva desses lances no tabuleiro, decreta-se a morte, um xeque-mate ao sentido: o fora-dosentido (do real, da letra, do gozo) vem sendo apresentado, ultimamente, como o supra-sumo conceptual do último ensino de Lacan, por J. A. Miller.

\section{Foraclusão induzida do sentido}

Com efeito, Miller (2001, 2002, 2003) vem, ultimamente, pregando dessa maneira a evolução do tabuleiro do maior discípulo de Freud: a «letra» do último ensino lacaniano, se lida à letra, e apostada juntamente com o gozo, o sintoma - como Torres, Cavalos ou Bispos, todos a serviço do Rei (o Real) - apontariam não apenas para um sem sentido, tal como se pensava, 
anteriormente, no ensino lacaniano da primazia do significante, mas para um radical fora-sentido ou fora-do-sentido. Quer nos convencer que, a partir de textos como Telévision e L'étourdit, nos anos setenta, o último Lacan teriase dado a uma zombaria generalizada do primeiro, da vertente do sentido, mesmo se fora ele próprio que tivera reintroduzido o sentido na psicanálise. Miller tenta costurar um diálogo Lacan contra Lacan, entre o último e o primeiro. O último Lacan zombou do sentido, é expressão farta na boca do discípulo, e a coisa não pára aí. Depois de ter promovido o sentido, Lacan teria passado para o sarcasmo do sentido até a sua rejeição. Ressalve-se: não uma simples rejeição, mas rejeição com ares fóbicos: da semantofilia à semantofobia diz na letra o discípulo dileto (pp. 19-20).

Assim, Miller insiste que o vetor do ensino do último Lacan seria o de uma "transmissão integral fora-do-sentido", uma elaboração da psicanálise fora-do-sentido, um viés que rejeita o sentido (2001, pp. 20-24). A rejeição do sentido não vem como algum ajuste local, mas com o cunho de uma verdadeira "transmutação" na psicanálise lacaniana; vem acompanhada de decorrências inteiramente antípodas ao que foi antes: implica a "desvalorização da palavra", melhor, "um tiro na palavra", melhor ainda, "um tiro na linguagem". E o tiro final: "ele [o último Lacan] desclassificou, é claro, seu conceito de linguagem, e também o conceito de estrutura..." (pp. 25-26). A fobia do sentido requisitada pela leitura milleriana, como a sarar e superar, esconjurar mesmo a filia semântica que tivera acometido seu mestre, à época que namorara a dama lingüística, na sua sedução estruturalista; eis o retrato proposto do último ensino de Lacan. Para meu entendimento isso leva a uma foraclusão induzida do sentido.

É de se ficar perplexo diante da certeza, celeridade, eveza até, e do modo incisivo pelo qual se procura propalar dessa maneira o último ensino de Lacan, com tantas e tantas decorrências - a meu ver, pouco pensadas que isso possa acarretar, seja para uma outra composição teórica, seja para alguma outra tática de escuta clínica. A questão do sentido é questão dura, muito mais séria epistemologicamente do que faz parecer a leveza com que se pretende poder excluí-lo, como se, declarando-o fora da cogitação, tudo estivesse resolvido. Mesmo porque, quando a dificuldade aparece, a coisa se 
resolve com uma pirueta: "O real é o nome positivo do fora-do-sentido, se bem que dar nomes coloca aqui efetivamente um problema", diz Miller e pula fora do problema, de pronto (2001, p. 26, itálicos meus).

Aqui não estamos diante apenas de um problema. Trata-se de todo o problema. É impossível conceptualizar algo em psicanálise ou em qualquer teoria sem definir, isto é, nomear. Um conceito, ao menos no que se refere a disciplinas não "duramente" científicas, é o nome de uma região semântica definida na inter-relação com os outros. E nomear é estabelecer diferenças semânticas entre os conceitos (real, gozo, letra...). É colocá-los de volta no regime das oposições de linguagem, visto que não há metalinguagem absolutamente exterior à linguagem, é pois entrar de cheio no regime do... sentido. Sem um pacto de sentido, não há como criar ou utilizar um conceito, muito menos acionar qualquer transmissão disso. Não se safa assim do sentido a baixo preço, por uma simples indução fóbica ou foracluísta imputada ao ensino de Lacan. De modo que o primeiro problema (não resolvido) de Miller não é a nomeação do real. O problema inteiro e imenso está na própria postulação do «fora-do-sentido», para conceitos ou para a transmissão. A própria idéia de algo "fora-do-sentido" só é possível porque há uma linguagem que nos permite intuir o "fora", por oposição a "dentro" "acima", "abaixo" etc., todos plenamente carregados de... sentido. Quanto a isso, então, o primeiro Lacan leva uma vantagem epistemológica ímpar sobre o último Lacan de Miller:

O poder de nomear os objetos [diz Lacan no mesmo seminário há pouco visto] estrutura a própria percepção. O percipi do homem só pode manter-se dentro de uma zona de nominação (...). A nominação constitui um pacto, pelo qual dois sujeitos, ao mesmo tempo, concordam em reconhecer o mesmo objeto. Se o sujeito humano não denominar (...) se os sujeitos não entenderem sobre esse reconhecimento, não haverá mundo algum, nem mesmo perceptivo, que se possa manter por mais de um instante" (Lacan, 1954-5/1992, p. 215).

Um segundo problema a enfrentar é que, assim posta, a psicanálise fora-do-sentido, ela estará inelutavelmente fora-da-linguagem, visto que estar na linguagem humana implica sempre a malha diferencial e opositiva entre sentidos, sejam quais forem seus limiares, partições e participações. Não se 
estará correndo aqui o risco de postular a «meta-linguagem» absoluta, contra algum Lacan, à escolha? Como isso ainda não foi cogitado, temos de aguardar a solução. Um terceiro problema também ronda. E o mesmo Miller se depara com ele: "Isso está evidentemente em tensão com uma análise, porque, na psicanálise, se conta histórias, a gente se conta em histórias, faz-se histórias" (2002, p. 16). Espera-se que isso não seja mera questão de detalhe, de modo que há que se resolver então a tensão de Miller - na verdade, a enorme aporia - de como ouvir tais histórias "fora-do-sentido". Por fim, haja suor para coordenar todas essas dificuldades com mais uma:

O último ensino de Lacan tende, pelo contrário, a aproximar a psicanálise da poesia, ou seja, de um jogo sobre os sentidos sempre duplos do significante. Sentido próprio e sentido figurado, sentido léxico e sentido contextual, isso é o que a poesia explora para, como diz Lacan, fazer violência ao uso comum da língua (Miller, 2003, p. 24, itálicos nossos).

É mesmo árdua a tarefa do pesquisador interessado tentar concatenar, no mesmo suposto último Lacan de Miller, a completa incongruência entre uma apologia do fora-do-sentido e, ao mesmo tempo, o elogio da poesia, jogo e criação, por excelência, de sentidos e efeitos de sentido. Sentido próprio, figurado, léxico e contextual, da última citação, nada mais é que a massa inteira, pesada, de todo o universo do sentido. Lacan sai do episódio dessa leitura vestido com a mortalha ambulante de um completo paradoxo. Por isso mesmo é difícil, para mim, convencer-me dessa inflexão lacaniana foracluísta do sentido.

O tabuleiro lacaniano e pós-lacaniano assim disposto é cruamente breve, concedo, mas suficiente a mostrar que, caso tudo tivesse sido diferente, talvez teria havido melhor diálogo, sobre a espinhosa questão do sentido, com as teorias do discurso e da significação, com as filosofias e epistemologias da linguagem, com as teorias semióticas e hermenêuticas, com todo o criticismo que nisso fosse exigido. A coisa teria avançado mais na direção do desafio freudiano frente ao "acúmulo de significações" do sonho, frente a seu estatuto semiótico. Mormente porque, no caso dessa teoria em partic ular, semiótica nada mais quer dizer senão a atitude de um duplo imperativo 
metodológico: o primeiro, positivo, a atitude investigativa que se impõe de dizer tudo sobre o sentido. Não a miragem da totalidade, Ïmas a tarefa da exaustividade: ir às primeiras instâncias do ser do sentido, isto é, as estruturas elementares que o criam, e às últimas instâncias do parecer do sentido, isto é, o modo como emerge nos discursos como significação manifestada, sonhos inclusive. «Onde o sentido está, lá deverei eu chegar», é como talvez a atitude semiótica poderia parafrasear, para si, o famoso dito freudiano, convertido em aforismo por Lacan. Quanto a isso, o próprio Lacan, o primeiro, tem a formulação mais justa:

Pois a descoberta de Freud é aquela do campo das incidências, na natureza do homem, das suas relações com a ordem simbólica, e o remontar [la remontée] de seu sentido até as instâncias as mais radicais da simbolização no ser. Desconhecer isso é condenar a descoberta ao esquecimento, a experiência à ruína. (1953, p. 275)

O segundo imperativo, negativo, é o controle metodológico do primeiro: semiótica é a atitude investigativa de não dizer tudo - no sentido de coisa qualquer, arbitrariamente - sobre o sentido. Há que buscar o sentido na imanência do texto, do dito, estendido ao contexto e aos interditos, e não a partir de asas livres do imaginário do investigador, sem controle, proliferado ou inflado por suas idiossincrasias hermenêuticas; há que extrair tudo, de sentido, do texto e contexto, mas não pôr coisa qualquer de sentido no texto, intertexto, dito ou interdito.

Assim entendidas as coisas, tenho, para mim, que a queixa freudiana sobre as muy escasas investigaciones a respeito do acúmulo de significações, permite destilar um sonho das investigações freudianas sobre o sonho. Esse sonho de Freud, para além de método clínico, teria sido quem sabe o de criar e fazer avançar o método de uma semiótica do discurso onírico, não importa se avant la lettre. O título do presente artigo não é, pois, o proselitismo de uma ou outra teoria, mas a homenagem aos votos de uma atitude de investigação. Se Lacan, na análise ilustrada, não foi o melhor exemplo para a atitude, deve-se debitar isso, antes, ao fato da precocidade das suas análises, e mesmo à antecipação de questões estruturais sobre a linguagem, sobre a enunciação, sobre o sentido, questões cruciais que poderiam ser levadas de 
melhor maneira, tivesse vingado melhor o diálogo, mal havido, com a lingüística e o diálogo não havido com as teorias do discurso, que só começaram a desenvolver-se ao final da década dos anos sessenta.

Entendidas igualmente assim as coisas, o leitor também ficará perplexo, como eu. Porque, se o Lacan de Miller subestimou mais e mais o sentido, se se desencantou com ele ao longo do seu ensino, se minimizou suas incidências, primeiramente, em prol do seu vazio irmão significante, desdém paulatino que, posteriormente, chega a descartá-lo inteiramente, no fim do seu ensino, para a região de um pretenso e derradeiro fora-sentido, imputado a conceitos tão pregnantes em psicanálise como o de real, de gozo, de letra, de sintoma; se isso for mesmo verificável, a darmos crédito ilimitado à leitura de Miller, então seremos forçados a nos perguntar se o império que Freud construiu às suas custas não teria sido mortalmente ferido sob o punho de seu "filho dileto": a epígrafe relembra a famosa frase romana. E o desfecho seqüente é que não há muitas outras saídas: se nada disso, dito acima, pode ser dito, com certeza, sobre Lacan, então, seremos forçados a outra conclusão.

Seja como tiver sido, uma coisa se torna inelutável: a única maneira conseqüente de se promulgar algum ensino, direção ou teoria, ancorada na sua base num apregoado fora-do-sentido é dizê-lo abertamente, e com todas as letras, uma orientação anti-freudiana. Caso contrário, as formulações não passarão de metafóricos lances locais de jogo, a provocar certos charmes momentâneos, inconseqüentes a longo prazo. De modo que penso ainda válido, conquanto tarefa por ser feita, reconvocar a psicanálise pós-freudiana e pós-lacaniana para a pesada tarefa da questão do sentido, examiná-la até as instâncias radicais da simbolização no ser, como disse, há pouco, Lacan, e fazê-lo de dentro, não de fora, independente de estruturalismos, modernismos ou pós-modernismos. Há vários parceiros atuais para a empreitada. Explorar, enfim, um pouco mais a aventura freudiana do sentido, no tabule iro vienense, no tabuleiro do primeiro Lacan, de toda a forma, no tabuleiro da linguagem, eis uma tarefa que permaneceu incomodamente deficitária. Mesmo porque, em definitivo, a questão do sentido não se põe fora, ela se impõe de dentro na práxis humana de linguagem. 
Beividas, W. (2004). Freud's Dream: Semiotic of the Oneiric Discourse. Psicologia USP, 15(3), 137-162.

\begin{abstract}
The author uses the most important dream analyzed in the Freudian Interpretation of Dreams, the Irma's injection dream, to support the idea that the creator of psychoanalysis has in this text inaugurated a "semiotic" understanding, avant la lettre, of the arduous question of sense. In face of the manner in which Freud arranged his method of dream interpretation, he sustains that the Lacanian analyses of this particular dream deserve remarks. According to the author they lack a broader discussion on the Freudian question of the accumulation of different meanings in this dream; they also resent the inexistence, back then, of a dialog between psychoanalysis and the theories that have the sense as their main object of investigation (discourse theories and semiotics). It is stated that the reasons of this deficit may be charged on the way Lacanian and post-lacanian psychoanalysis have conducted the concept of sense, gradually disregarded and abandoned, if not openly excluded from their current cogitations.
\end{abstract}

Index terms: Psychoanalysis. Semiotics. Dreaming.

Beividas, W. (2004). Le rêve de Freud. Sémiotique du discours onirique Psicologia USP, 15(3), 137-162.

Résumé: L'auteur utilise du texte de la Science des rêves de Freud, plus exactement, le rêve majeur de l'injection d'Irma, pour défendre l'idée que le créateur de la psychanalyse a inauguré avec ses analyses une réflexion 'sémiotique' avant la lettre, sur la question épineuse du sens. Devant la façon dont Freud a disposé sa méthode d'interprétation, les analyses lacaniennes de ce même rêve méritent des reproches parce que justement elles se ressentent du manque d'une discussion plus serrée sur la question freudienne de l'accumulation de significations dans le rêve, elles se ressentent du manque d'un dialogue non tenu entre la psychanalyse et les théories qui ont le sens comme son propre objet de recherche (la sémiotique). L'auteur entend que les raisons de ce déficit doivent être débitées de la manière dont la psychanalyse lacanienne, et surtout postlacanienne, ont pris le concept de sens, peu à peu dédaigné, ignoré, voire ouvertement exclu de ses cogitations actuelles (cf. les propositions de Miller sur le hors-sens).

Mots clés: Psychanalyse. Sémiotique. Sens. 


\section{Waldir Beividas}

\section{Referências}

Beividas, W. (2002). Inconsciente et verbum Psicanálise, semiótica, ciência, estrutura (2a ed.). São Paulo: Humanitas.

Beividas, W., \& Lopes, M. (2004). Psicanálise e lingüística: uma relação «mal começada». Pulsional - Revista de Psicanálise, (177).

Freud, S. (1973). Estudios sobre la histeria. In S. Freud, Obras Completas (3a ed., tomo I, pp. 39-168). Madrid: Biblioteca Nueva. (Trabalho original publicado em 1895)

Freud, S. (1973). La interpretación de los sueños. In S. Freud, Obras Completas (3a ed., tomo I, pp. 343-720). (Trabalho original publicado em 1900)

Freud, S. (1973). Sobre psicoterapia. In S. Freud, Obras Completas (3a ed., tomo I, pp. 1007-1013). Madrid: Biblioteca Nueva. (Trabalho original publicado em 1904)

Freud, S. (1973). Lecciones introductorias al psicoanálisis. Leccion ii - Los actos fallidos. In S. Freud, Obras Completas (3a ed., tomo III, pp. 2131-2140). Madrid: Biblioteca Nueva. (Trabalho original publicado em 1915-17)

Freud, S. (1973). Construcciones en psicoanálisis. In S. Freud, Obras Completas (3a ed., tomo II, pp. 3365-3373). Madrid: Biblioteca Nueva. (Trabalho original publicado em 1937)

Grünbaum, A. (1984). Les fondements de la psychanalyse. Paris: PUF.

Lacan, J. (1953). Fonction et champ de la parole et du langage en psychanalyse. In J. Lacan, Ecrits (pp. 237-322). Paris: Seuil.

Lacan, J. (1992). O seminário. Livro 2. O eu na teoria de Freud e na técnica da psicanálise (3a ed.). Rio de Janeiro: Zahar. (Trabalho original publicado em 1954-1955)

Lacan, J. (1974). Télévision. Paris: Seuil.

Masson, J. M.(1984). Atentado à verdade. A supressão da teoria da sedução por Freud. Rio de Janeiro: J. Olímpio.

Miller, J.-A. (2001). Psicanálise pura, psicanálise aplicada \& psicoterapia. Phoenix n.3 (pp. 9-43). Curitiba: EBP-Del.

Miller, J.-A. (2002). O real é sem lei. Opção Lacaniana (34), 7-16.

Miller, J.-A. (2003). O último ensino de Lacan. Opção Lacaniana (35), 5-24.

Sulloway, F. J. (1998). Freud, biologiste de l'esprit. Paris: Fayard. (Trabalho original publicado em 1979)

Zizek, S. (2001, 8 de abril). A fuga para o real. Mais FSP, 8-12.

Recebido em 25.07.2003

Aceito em 04.12.2003 